\section{REVISITING THE FINANCIAL ISSUES AND THE IMPACT TO CONSTRUCTION PROJECTS IN MALAYSIA}

\author{
Mohd Ashraf Mohd Fateh ${ }^{a^{*}}$, Tan Hee Yee
}

${ }^{a}$ Centre of Studies for Construction Faculty of Architecture, Planning \& Surveying, Universiti Teknologi MARA, 40450 Shah Alam, Malaysia. bepartment of Civil Engineering, Infrastructure University Kuala Lumpur, Jalan Ikram-Uniten, 43000 Kajang, Selangor Darul Ehsan, Malaysia.
Article history

Received

2 November 2020

Received in revised form

7 June 2021

Accepted

8 June 2021

Published online

30 July 2021

\author{
*Corresponding author \\ mohdashraf@uitm.edu.my
}

\begin{abstract}
Every activity in a construction project is related to time and cost. Delay is considered common and often occurred in a construction project. A slight delay can be very costly. It will impact all of the related stakeholders. This paper seeks to identify the financial issues in the construction industry and the impact of the financial issues towards the projects in Malaysia. Literature reviews and questionnaire surveys were used to carry out the study. The data collected were analysed via Microsoft Excel and SPSS software. The paper reveals that the withholding of payment by the approval parties is the critical financial issues in Malaysia's construction industry, while the main impact when the financial issues occurs is where the project is delayed/postponed/terminated. The findings of this research will give a good insight to the industry and help to improve the local players' competitive capabilities as highlighted by the Construction Industry Development Board (CIDB) in the Construction Transformation Programme (CITP) 2016-2020 and in line with the Sustainable Development Goals (SDGs) that was introduced by the United Nations (UN).
\end{abstract}

Keywords: I Financial Issues, impact, revisit, construction, Malaysia

(C) 2021 Penerbit UTM Press. All rights reserved

\subsection{INTRODUCTION}

Malaysia is working actively towards achieving a high-income status year over year. According to the (Uzir, 2019), the construction sector contributed around $4.0 \%$ of the Gross Domestic Product (GDP). Since the construction industry's economy is growing year over year, many challenges will arise during the construction projects implementation. The main challenge that contractors and construction projects are facing in executing construction work are the delays, which is a global phenomenon as reported by (Shahsavand et al., 2018). The delay will lead to various negative effects such as abandoned projects, financial losses, bad reputations, and legal issues. The construction project consists of various activities. It is a complex task that requires all the parties involved (clients, contractors and consultants) to carry out specific responsibilities. Any projects that are able to complete on time, offers a lot of benefits to all the stakeholders such as boosting up the reputation of each organisation involved and contributing to the country's economic growth. Nevertheless, a delay is an inherent issue in the construction projects as reported by (Shahsavand et al., 2018). Malaysia is no exception on this issue. The government has acknowledged that the delays in the construction project are a 'big headache' which will bring a lot of negative consequences as reported by Hisham and Yahaya (2007) and Safri (2009). Therefore, to prevent and reduce delays are vital for the construction projects. According to Driscoll (2014), by understanding and managing the causes of the delays, the related stakeholders will be able to develop an efficient and effective schedule to complete the project successfully. There are a lot of factors that caused the delays, such as inaction or delay of the participants, design errors or scope change, workplace incidents or financial issues as reported by Abdul-Rahman, Takim and Min (2009). This paper will attempt to identify the financial issues in the construction industry which are the most critical factors that cause delays in the construction project and to identify the impact of the financial problems towards the project.

From this scenario, this research is provoked to be conducted in line with the agenda of the Construction Industry Transformation Programme (CITP), and to improve the competitive capabilities of the local players as reported by the Construction Industry Development Board (CIDB), 2015. This was agreed by Mohd Fateh and Mohammad (2017), that the 
CITP's vision is to transform the construction industry to become highly productive, sustainable and competitive globally while raising the industry's professional bar. This initiative is parallel with the Sustainable Development Goals (SDGs) introduced by the United Nations (UN) in 2018 that targeted developing countries where they will be able to sustain the economic growth per national circumstances under Goal No. 8 as reported by the UN, (2020).

This paper is structured into three parts. Firstly, the review covers a broad range of literature providing an overview of the construction industry, factors contributing to delays and the impacts of financial issues towards the project. The second part discusses on the methodology used for this paper. The last part covers the findings and conclusions derived from evidence from the literature review and questionnaire survey.

\subsection{LITERATURE REVIEW}

\subsection{The Construction Industry}

Mordor Intellengence (2019), reported that the A CAGR of $4.7 \%$ over the forecast period, 2019-2024, is expected to be posted in the Malaysian construction sector. During 2010-2016, the Malaysian construction industry reported an average annual growth rate of 7.9 percent. The 10th Malaysia Plan 2011-2015 supported this development, under which the government invested heavily in infrastructure, industrial parks, and residential buildings. This was agreed by Mohd Fateh, Zakariah and Ema Ezanee (2020), stated that the growth is the affordable housing projects, slightly due to the rise in new expected supplies. There are various construction projects in the pipeline to boost up the growth such as to improve the transportation system and the infrastructure for the tourism sector as reported by Mordor Intellengence (2019). Hussain (2015) and Mohd Fateh, Zakariah and Emma Ezanee (2020), highlighted that the construction industry is one of Malaysia's key economic drives since the industry was able to offer goods and services. The construction industry's goods and services go across different sectors such as commercial, residential, industrial, infrastructure, energy and utilities. Mohd Fateh and Mohammad (2017), also added that the construction industry has been a real driver for the economic growth witnessed in recent years, as the production of infrastructure has been at the core of the cycle.

\subsection{Delay in the Construction Industry}

Today, the construction industry faces various challenges as reported by Mohd Fateh and Nijar (2019). One of the common issues lingering in the construction industry is a delay. Delay is described as an event that causes a longer period of time to complete all or part of a project according to Othuman Mydin et al. (2014). In the construction industry, a delay is a global phenomenon. This was agreed by Shahsavand, Marefat and Parchamijalal (2018), stated that a delay is the time over beyond the date of completion that was stated in the contract. Construction project delays can be classified into two ( 2 ) main categories of internal and external causes. Internal factors emerge from contract parties, such as contractors, clients, and consultants. External causes emerge from events beyond the control of the participants as reported by Hisham and Yahaya (2007). Fugar and Agyakwah-Baah (2010), added that the delays could be classified into three (3) types. Firstly, Excusable but non-compensable postponement. There are delays created by incidents not due to either of the parties. Followed by the compensable pause. Such delays are the result of actions or omissions by the owner or anyone for whom the owner is responsible. Lastly, the inexcusable postponement. These delays occur from the negligence of a contractor or his subcontractors or suppliers of materials.

\subsection{Factors Contributing to a Delay}

Syahira Nabila Ahmad and Kharulzan Yahya (2007), highlighted that there were six (6) factors that could contribute to a delay namely, contractor-related factors, client-related factors, material-related factors, consultant-related factors, labour and equipment-related factors and financial-related factors. The most critical factor that causes delays in the construction projects is a financial-related factor as stated by Alaghbari et al. (2007) and Abdul-Rahman, Takim and Min (2009). In the Malaysian construction projects, delays that cause by the possible financial-related factors are the client's financial issues such as financial difficulties, delayed payment, and economic problems; cash flow and financial problems of the contractor; or bad economic conditions such as inflation and the currency rate are an external factor as reported by Ahmed (2003). This was supported by Frimpong and Oluwoye (2003) and AbdulRahman, Takim and Min (2009), stated that the main causes of delays were the financial issues. Assaf and Al-Hejji (2006), stated that the construction sector was always struggling with the problems of late payment. Late payment will cause the deterioration of cash flow for a contractor; subsequently, the contractor may not be able to pay for the labour wages or construction materials, therefore the delay arises. This was agreed by Ren, Atout and Jones (2008), listing the root causes of late payment as clients' poor business and financial management, payment withholds by the client, an invalid claim by contractors, delay in valuation and certification of the consultant's interim payment, inaccurate valuation of work done, inadequate information and documentation for valuation, too many people are involved in the certificate honouring process, heavy workload of the contractor to carry out the review of the work completed and misunderstanding by the contractor of the provision of a variation order by the client. Kaming et al. (1997), stated that one of the most important factors that could cause delays in the construction projects was the lack of financial resources due to poor control of cash flow. This was agreed by Muller and Ward (2013), added that a well-managed cash flow played an important role in delivering a successful project within the contract period. Therefore, it is important to evaluate the impact of any financial issues that are able to ensure adequate cash flow for a project.

\subsection{METHODOLOGY}

Literature review and questionnaire survey were used for this paper. The questionnaire was distributed to three (3) groups of construction industry players namely clients, contractors and consultants. Forty (40) sets of questionnaires were distributed 
to each group which brings to 120 sets of the questionnaire in total, within a three (3) months' time frame. Awang (2012), suggested to integrate the technological advantages with a questionnaire survey that allowed faster collection and analysis of data; all questionnaire surveys were distributed online. All the data collected were analysed using Microsoft Excel and SPSS software.

Mohd Fateh, Zakariah and Ema Ezanee (2020), recommended to conduct a pilot study before the distribution of the questionnaire to detect some weaknesses. Thus, after completing the pilot exercise, the amendments were made, the number of questions decreased, the formats of the questionnaire were restructured and the scale used was changed. The questionnaire for the survey is broken down into four (4) parts. Summaries of the segment are as follows:

- Part 1: It will be the landing page where the survey's study title, history and goals can be specified by respondents.

- Part 2: This section focuses on the demographics of the respondents (background), which include the age group, organisational field, level of education, appointment, years of experience in construction project management and industry as a whole.

- Part 3: Identification of financial issues in the construction sector has been reported in this section. The questionnaires are designed using 5-point Likert Scale to classify regularly the challenges encountered by the respondents.

- Part 4: The researcher wishes to identify in this section the effects of the construction industry's financial problems. The questionnaires are prepared to understand the seriousness of the impacts using 5-point Likert Scale.

The respondents can also write down any thoughts or ideas related to the research in every section of the survey.

\subsection{RESULTS AND DISCUSSION}

Ninety (90) out of a total of 120 answers were received, which translated into $75 \%$ response rate. According to Fellows and Liu (2008), for a self-administered questionnaire for study in the construction industry, usually about 25 to 35 percent response rate, therefore this is considered appropriate. The importance of this problem and the relevance of the analysis to the industry have been justified and valid by conducting a preliminary study with a number of players in the construction industry. Nevertheless, as this work is still underway, therefore when this paper was being written, the information given in this paper was only the findings of the questionnaire survey.

\subsection{Internal Consistency (Reliability Test)}

Reliability test was conducted to measure the internal consistency of the questionnaire survey. Twenty (20) items were calculated using the Cronbach's Alpha formula and it obtained 0.795 , this suggested that the items were interrelated and compatible with the study sample; the interval consistency level is, therefore, appropriate as stated by Pallant (2011). According to Sekaran and Bougie (2009), the lower Cronbach's Alpha is to 1 , increasing the strength of the internal consistency.

\subsection{Demographic of the Respondents}

From the total of 90 respondents, $35 \%$ (31) were consultants, $33 \%$ (30) were contractors and $32 \%$ (29) were clients as illustrated in Table 1. It showed that the distribution of the respondents was not inclined to only one sector. This is vital to ensure that the findings are not biased to only one sector. $28 \%$ (25) of the respondents were 50 years old and above, followed by $21 \%$ (19) were 31 to 35 years old, then $20 \%$ (18) were 26 to 30 years old, $17 \%$ (15) were 40 to 45 years old and lastly $14 \%$ (13) were 20 to 25 years old. Thus, Table 2 summarises on the age of the respondents. Many of the respondents who took part in the survey had extensive experience in the construction field.. According to Table 3, 37\% (33) of the respondents had more than 15 years of experience in the construction industry, $28 \%$ (25) with 5 to 10 years of construction industry experience followed by $19 \%$ (17) of respondents with 10 to 15 years of construction industry experience and lastly $16 \%(15)$ have only 1 to 5 years of construction industry experience. From this finding, it illustrated that the majority of the respondents have a significant experience in the construction industry, thus it was considered to be valid and reliable for the questionnaire survey.

Table 1: Respondent's Sectors

\begin{tabular}{ccc}
\hline Respondent's Sectors & No of Respondents & Percentages (\%) \\
\hline Client & 29 & 35 \\
\hline Contractors & 30 & 33 \\
\hline Consultant & 31 & 32 \\
\hline TOTAL & 90 & 100 \\
\hline
\end{tabular}

Table 2: Respondent's Age

\begin{tabular}{ccr}
\hline Respondent's Age & No of Respondents & Percentages (\%) \\
\hline $20-25$ & 13 & 14 \\
\hline $26-30$ & 18 & 20 \\
\hline $31-35$ & 19 & 21 \\
\hline $40-45$ & 15 & 17 \\
\hline 50 and above & 25 & 28 \\
\hline TOTAL & 90 & 100 \\
\hline
\end{tabular}


Table 3:Years of experience in the Construction Industry from Respondent

\begin{tabular}{ccc}
\hline Years of experience in the Construction Industry from Respondent & No of Respondents & Percentages (\%) \\
\hline 1 to 5 years & 15 & 16 \\
\hline 5 to 10 years & 25 & 25 \\
\hline 10 to 15 years & 17 & 19 \\
\hline 15 years and above & 33 & 37 \\
\hline TOTAL & 90 & 100 \\
\hline
\end{tabular}

From the analysis, it was concluded that the main financial problem is the withhold payment by the approval parties (Mean: 3.99). The standard deviation also indicated that the variance of views from the respondents was relatively small. This was followed by a delay in valuing and certifying the provisional payment (Mean:3.77) and inflation of increases in goods, salaries for labour and transport costs (Mean: 3.62). On the other hand, the least financial problems in the construction industry are the increment of the foreign exchange rate which has the smallest impact on the financial profile of the company (Mean: 2.88). It might be due to the fact that most of the respondents' organisations did not have an impact directly on the foreign exchange rates since most of the trading used local currency. Table 4 summaries the findings for the financial issues in the construction industry.

Table 5 illustrated the main impact when the financial issues arises in the construction project which could lead to project delay/postpone/shutdown (Mean: 4.19). This was followed by a shortage of labour to proceed with the work (Mean: 3.81) and this tarnished the organisation's reputations (Mean: 3.66). The least impact of financial problems towards the construction project is the bankruptcy of the organisation (Mean: 1.69). This may be due to the impact which will hit the construction project first and if the problems prolonged, then it will affect the organisation directly or indirectly.

Table 4 Financial Issues in the Construction Industry (N:90)

\begin{tabular}{lll}
\hline \multicolumn{1}{c}{ Financial Issues in the Construction Industry } & Mean & Standard Deviation \\
\hline Withhold of Payment by Approval Parties & 3.99 & 1.12 \\
\hline Delay in Valuing and Certifying The Provisional Payment & 3.77 & 1.42 \\
\hline Inflation of Increases in Goods, Salaries for Labour and Transport Costs & 3.62 & 1.20 \\
\hline Inaccuracy of Valuation & 3.55 & 1.30 \\
\hline Poor Cashflow Management & 3.10 & 1.29 \\
\hline Increment of Foreign Exchange Rate & 2.88 & 1.53 \\
\hline
\end{tabular}

Table 5 Impact of Financial Issues Towards the Construction Project (N: 90)

\begin{tabular}{lll}
\hline \multicolumn{1}{c}{ Impact of Financial Issues Towards the Construction Project } & Mean & Standard Deviation \\
\hline Project Delay / Postponed / Shutdown & 4.19 & 0.99 \\
\hline Shortage of Labour to Proceed with the Works & 3.81 & 1.26 \\
\hline Tarnish of the Organization's Reputations & 3.66 & 1.32 \\
\hline Leads to Legal Dispute & 2.11 & 1.10 \\
\hline The bankruptcy of the Organization & 1.69 & 0.98 \\
\hline
\end{tabular}

\subsection{CONCLUSIONS}

Based on the findings, withholding of payment by the approval parties was the critical financial issues in the construction industry. The findings were similar as reported by Abdul Rahman, Takim and Min (2009). It showed that the financial issues were still haunting the construction industry. Most of the respondents agreed that the issue was troublesome if the payment did not go through on time. The cash flow is the lifeblood for every organisation in the construction industry. The organisation needs to service other business dealings such as purchasing material, sub-contractors and its overheads. When the financial problem occurred, it will impact the project directly which leads to project delay, postponed or even shutdown. This will propel and snowball into other issues such as bad quality of the project deliverables and unhappy endusers. From this study, it showed that financial issues in the construction industry are still lingering until this day and age. Revising the approaches on how to minimise or prevent the issues is necessary. Even though every construction project is unique and dynamic, but financial issues are considered as the fundamental aspect of every construction project. It needs to be sorted out and look into. Therefore, research into this field is crucial, which is expected to give the players in the construction industry and related stakeholders a guideline. The results of this study will provide a good insight into the field and help strengthen the competitive capabilities of the local players as demonstrated by the CIDB and in line with the SDGs introduced by the UN. 


\section{Acknowledgements}

The article is part of the ongoing research work carried out at Universiti Teknologi Mara (UiTM) by the researcher. Acknowledgements are also owed to CIDB and UiTM, which are involved in the entire research process directly or indirectly.

\section{References}

[1] Abdul-Rahman, H., Takim, R. and Min, W. S. (2009) 'Financial-related causes contributing to project delays', Journal of Retail and Leisure Property, 8(3), pp. 225-238. doi: 10.1057/rlp.2009.11.

[2] Ahmed, S. (2003) 'Sources of economic fluctuations in Latin America and implications for choice of exchange rate regimes', Journal of Development Economics. 72(1): 181-202. doi: https://doi.org/10.1016/S0304-3878(03)00073-7.

[3] Alaghbari, W. et al. (2007) 'The significant factors causing delay of building construction projects in Malaysia', Engineering, Construction and Architectural Management. 14(2): 192-206. doi: 10.1108/09699980710731308.

[4] Awang, Z. (2012) Research Methodology and Data Analysis. 2nd Editio. Selangor: UiTM Press

[5] Bryman, A. and Bell, E. (2015) Business research methods. 3rd edn. New York: Oxford University Press.

[6] Chua, Y. P. (2016) Mastering Research Methods. 1st edn. Malaysia: McGraw-Hill.

[7] Construction Industry Development Board (CIDB) (2015) Construction Industry Transformation Programme 2016 - 2020. Kuala Lumpur.

[8] Driscoll, T. J. (2014) Managing the Time Factor. Marlton. Available at: https://www.hka.com/home/blog/2013/09/11/managing-the-timefactor/.

[9] Fellows, R. and Liu, A. (2008) Research Methods for Construction. 3rd edn. USA: Wiley-Blackwell.

[10] Frimpong, Y. and Oluwoye, J. (2003) 'Significant Factors Causing Delay and Cost Overruns in Construction of Groundwater Projects in Ghana', Journal of Construction Research, 04: 175-187. doi: 10.1142/S1609945103000418.

[11] Fugar, F. D. and Agyakwah-Baah, A. B. (2010) 'Delays in Building Construction Projects in Ghana', Construction Economics and Building, 10(1-2): 103-116. doi: 10.5130/ajceb.v10i1-2.1592.

[12] Hisham, S. N. A. and Yahaya, K. (2007) 'Causes and effects of delays in Malaysian construction industry', International Journal of Project Management, 25(5): 517-526.

[13] Hussain, M. R. (2015) Malaysia Productivity Corporation (MPC). Kuala Lumpur. Available at: http://www.mpc.gov.my/.

[14] Kaming, P. F. et al. (1997) 'Factors influencing construction time and cost overruns on high-rise projects in Indonesia', Construction Management and Economics. Routledge, 15(1): 83-94. doi: $10.1080 / 014461997373132$
[15] Mohd Fateh, M. A. and Mohammad, F. M. (2017) 'IBS Provision in Local and International Standard Form of Contracts', Journal of Construction in Developing Countries 22(2): 1-12.

[16] Mohd Fateh, M. A. and Nijar, N. N. (2019) 'Perspective Analysis on Ibs Provision in Standard Form of Contract in Malaysia', Malaysian Construction Research Journal, 6(1): 87-105.

[17] Mohd Fateh, M. A., Zakariah, H. and Ema Ezanee, S. (2020) 'Improvement for significant clauses in the standard form of contract for industrialized building system construction', IOP Conference Series: Materials Science and Engineering, 713(1): 1-13. doi: 10.1088/1757-899X/713/1/012037.

[18] Mordor Intellengence (2019) Malaysia Construction Market - Growth, Trends, And Forecast (2020 - 2025). Hyderabad. Available at: https://www.mordorintelligence.com/industry-reports/malaysiaconstruction-market-growth-trends-and-forecast-2019-2024.

[19] Morse, J. M. and Niehause, L. (2016) Mixed Method Design: Principles and Procedures. 4th edn. London: Routledge. Available at: https://books.google.com.my/books?id=UV2IDAAAQBAJ\&dq=morse+ 1991\&source=gbs_navlinks_s.

[20] Muller, C. and Ward, M. (2013) 'Style-based effects on the Johannesburg Stock Exchange: A graphical time-series approach', Investment Analysts Journal, 77(1): 1-16. doi: 10.1080/10293523.2013.11082552.

[21] Othuman Mydin, M. A. et al. (2014) 'Imperative causes of delays in construction projects from developers' outlook', MATEC Web of Conferences, 10. doi: 10.1051/matecconf/20141006005.

[22] Pallant, J. (2011) For the SPSS Survival Manual. 4th edn.

[23] Ren, Z., Atout, M. and Jones, J. (2008) 'Root causes of construction project delays in Dubai', Association of Researchers in Construction Management, ARCOM 2008 - Proceedings of the 24th Annual Conference, 2(September): 749-757.

[24] Safri, D. S. (2009) A Comparative Study of Construction Project Delays in Malaysia (Johor and Sabah Region). Universiti Teknologi Malaysia. Available http://eprints.utm.my/id/eprint/12698/1/DayangSabriahSafriMFKA2 009.pdf. Access date: 1 April 2020

[25] Sekaran, U. and Bougie, R. (2009) Research methods for business: A skill building approach. 5th edn. United Kingdom: John Wiley \& Sons.

[26] Shahsavand, P., Marefat, A. and Parchamijalal, M. (2018) 'Causes of delays in construction industry and comparative delay analysis techniques with SCL protocol', Engineering, Construction and Architectural Management, 25(4): 497-533. doi: 10.1108/ECAM-102016-0220.

[27] Syahira Nabilla Ahmad and Kharulzan Yahya (2007) 'Causes and effects of delays in Malaysian construction industry', International Journal of Project Management, 25(5): 517-526.

[28] United Nations (2020) The Sustainable Development Goals Report 2020. New York. Available at: https://unstats.un.org/sdgs/report/2020/The-SustainableDevelopment-Goals-Report-2020.pdf. Access date: 3 April 2019 